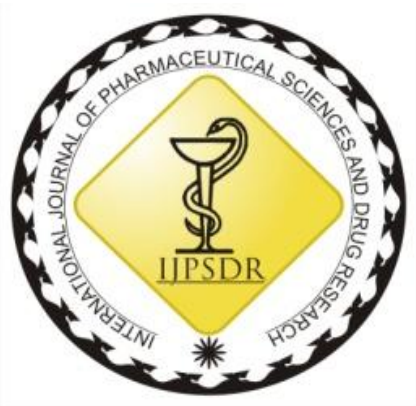

\author{
RESEARCH ARTICLE
}

ISSN: 0975-248X CODEN (USA): IJPSPP $(\mathrm{cc})$ EY-NC-SA

\title{
GC-MS Analysis of Bioactive Compounds of Ethanolic Seed Extract of Elaeocarpus serratus
}

\author{
DH Geetha*, Indhiramuthu Jayashree, M Rajeswari \\ PG and Research Department of Botany, Vellalar College for Women, (Autonomous), Erode- 638012, Tamil Nadu, India \\ Copyright (C) 2018 DH Geetha et al. This is an open access article distributed under the terms of the Creative Commons Attribution- \\ NonCommercial-ShareAlike 4.0 International License which allows others to remix, tweak, and build upon the work non-commercially, as long as \\ the author is credited and the new creations are licensed under the identical terms.
}

\begin{abstract}
The present investigation was carried out to determine the possible bioactive compounds of ethanolic extract of Elaeocarpus serratus (Elaeocarpaceae) has been subjected to GC-MS analysis. Thirty compounds were detected from the plant E. serratus. The highest peak area percentage of $19.12 \%$ was obtained by n-propanol (RT=3.04min.) and lowest peak area percentage of $2.34 \%$ was obtained by 1 -propylthio-3,3,3-trifluoropropyl acetate (RT=11.57min.). The presence of various bioactive compounds confirms many aliments by traditional practitioners. However, isolation of individual phytochemical constituents may proceed to find a novel drug.
\end{abstract}

Keywords: Elaeocarpus serratus, GC-MS, bioactive compounds, propanol.

\begin{tabular}{l}
\hline DOI: 10.25004/IJPSDR.2019.110105 Int. J. Pharm. Sci. Drug Res. 2019; 11(1): 31-34 \\
\hline \hline \\
*Corresponding author: Dr. DH Geetha \\
Address: PG and Research Department of Botany, Vellalar College for Women, (Autonomous), Erode- 638012, Tamil Nadu, India \\
E-mail $₫:$ geethadhandapani2010@gmail.com \\
Relevant conflicts of interest/financial disclosures: The authors declare that the research was conducted in the absence of any commercial or \\
financial relationships that could be construed as a potential conflict of interest. \\
Received: 24 November, 2018; Revised: 20 December, 2018; Accepted: 02 January, 2019; Published: 20 January, 2019 \\
\hline
\end{tabular}

\section{INTRODUCTION}

From ancient days to recent civilization, human beings depend on nature for running their life smoothly from day by day. Plants remain a vital source of drugs and now-a-days much emphasis has been given to nutraceuticals. [1] Natural remedies from medicinal plants are found to be safe and effective. Many plants species have been used in folkloric medicine to treat various ailments. Even today compounds from plants continue to play a major role in primary health care as therapeutic remedies in many developing countries. [2] Standardization of plant materials is the need of the day. Several pharmacopoeia containing monographs of the plant materials describe only the physicochemical parameters. Hence the modern methods describing the identification and quantification of active constituents in the plant material may be useful for proper standardization of herbals and its formulations. [3] Medicinal plants as sources of bioactive compounds continue to play a dominant role in the maintenance of human health. Reports available on plants represent a reservoir of effective chemotherapeutants, nonphytotoxic, more systemic and easily biodegradable. [45] The genus Elaeocarpus species contain hard and highly ornamental stony endocarp of fruit commonly known as 'Rudraksh'. Rudraksha bead users have repeatedly confirmed the medicinal properties like antipyretic, anti-helminthic, reduce blood pressure, anti-paralysant and chemo preservative. [6] Several species have been known to possess cardiovascular stimulant, anti-viral, pesticide and anti-tumor activity, anti-asthmatic and anti-inflammatory, antiseptic, 
ulcers, piles and leprosy. [7-8] Elaeocarpus serratus are used in the treatment of anti-arthritic [9-10], antimicrobial [11-12] and anti-diabetic activity [13-14], GC-MS analysis ${ }^{[15-16]}$ of the plant extract. The literature search reveals that still no work has been done on this plant part. Hence this work was carried out to profile chemical compounds from ethanolic extract of $E$. serratus.

\section{MATERIALS AND METHODS}

\section{Plant material}

The seed of Elaeocarpus serratus L. were collected from Upper Palani Hills of Western Ghats (Kodaikanal Forest Division), India and were authenticated at Botanical Survey of India (BSI), Southern Circle, Coimbatore, India and the herbarium of Voucher specimen number BSI/SRC/5/23/2011-12/Tech. 454 has been deposited at the PG and Research Department of Botany, Vellalar College for Women, Erode (T.N), India.

\section{Preparation of Plant extract}

Seeds were collected and air-dried at room temperature. The dried material was then homogenized to obtain coarse powder and stored in air-tight bottles for further analysis. The shade dried, powder seed were extracted [17] with ethanol solvent by hot extraction using soxhlet apparatus collected and stored in a vial for further analysis.

\section{GC-MS Analysis}

Ethanolic extract of seed of E. serratus were analyzed for the presence of different compounds by GC-MS technique. GC-MS analysis of some of the potent volatile constituents present in the extracts was performed at The South India Textile Research Association (SITRA), Coimbatore (Tamil Nadu), India. GC analysis of the extracts was performed using a GC-
MS (Model; Thermo Trace GC Ultra) equipped with a DB-5MS fused silica capillary column (30 m length $\times$ outside diameter $0.25 \mathrm{~mm} \times$ internal diameter $0.25 \mu \mathrm{m}$ ) and gas chromatograph interfaced to a Mass Selective Detector (MS-DSQ-II) with XCALIBUR software. For GC-MS detection, an electron ionization system with ionization energy of $-70 \mathrm{eV}$ was used. Helium gas was used as a carrier gas at a constant flow rate of $1 \mathrm{ml} / \mathrm{min}$ and the sample injected was $2 \mu \mathrm{l}$; Injector temperature $250^{\circ} \mathrm{C}$; Ion source temperature $200^{\circ} \mathrm{C}$. The oven temperature was programmed from $80^{\circ}$ to $200^{\circ} \mathrm{C}$ at the rate of $10^{\circ} \mathrm{C} / \mathrm{min}$, held isothermal for $1 \mathrm{~min}$ and finally raised to $260^{\circ} \mathrm{C}$ at $10^{\circ} \mathrm{C} / \mathrm{min}$. Interface temperature was kept at $250^{\circ} \mathrm{C}$. Total GC run time was $46.16 \mathrm{~min}$. The relative percentage of the each extract constituents was expressed as percentage with peak area normalization.

\section{Identification of components}

The identity of the components in the extract was assigned by the comparison of their retention indices and mass spectra fragmentation patterns with those stored on the computer library and also with published literatures. NIST [18], WILEY [19] library sources were also used for matching the identified components from the plant material.

\section{RESULTS AND DISCUSSION}

The GC-MS analysis of ethanolic extract of seed of Elaeocarpus serratus revealed the presence of thirty bioactive compounds that could contribute the medicinal quality of the plant. The identification of the chemical compounds was confirmed based on the retention time, molecular formula, molecular weight and peak area in percentage were depicted in Figure 1 and Table 1.

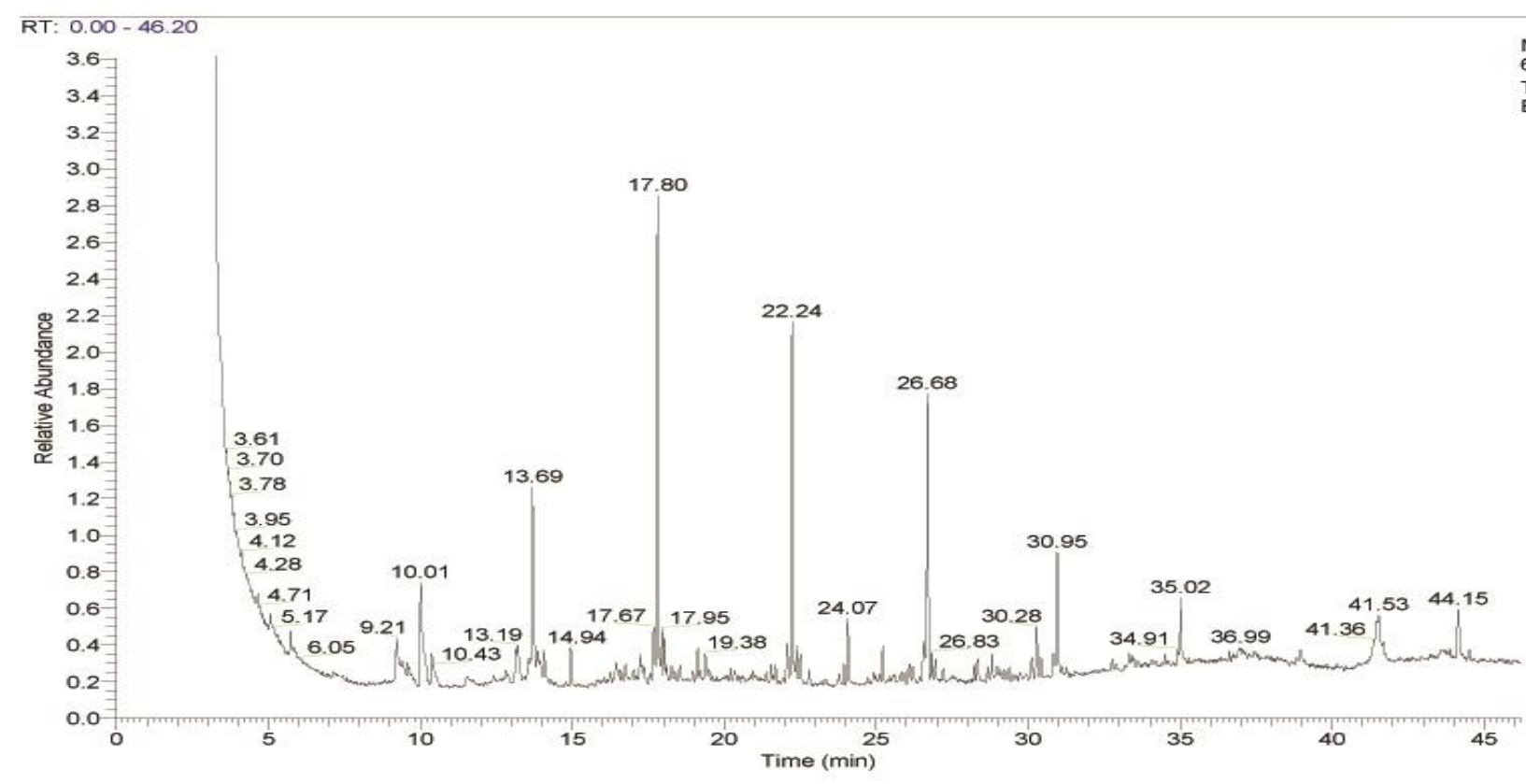

Fig. 1: GC-MS chromatogram of ethanolic extract of the seed of Elaeocarpus serratus 
DH. Geetha et al. / GC-MS Analysis of Bioactive Compounds of Ethanolic Seed Extract of Elaeocarpus...........

Table 1: GC-MS analysis of the ethanolic extract of seed of Elaeocarpus serratus

\begin{tabular}{|c|c|c|c|c|c|}
\hline S. No. & RT & Name of the compound & Molecular formula & Molecular weight & Peak area $\%$ \\
\hline 1. & 3.04 & n-Propanol & $\mathrm{C}_{3} \mathrm{H}_{8} \mathrm{O}$ & 60 & 19.12 \\
\hline 2. & 5.74 & 4-methyl-4-nitro-5-oxoheptanal & $\mathrm{C}_{8} \mathrm{H}_{13} \mathrm{NO}_{4}$ & 187 & 0.86 \\
\hline 3. & 9.23 & 2-Bromomethyl-1-oxaspiro[2.4]heptane & $\mathrm{C}_{7} \mathrm{H}_{11} \mathrm{BrO}$ & 190 & 1.65 \\
\hline 4. & 10.03 & N-Allyloxymethylacrylamide & $\mathrm{C}_{7} \mathrm{H}_{11} \mathrm{NO}_{2}$ & 141 & 4.21 \\
\hline 5. & 10.41 & $\begin{array}{l}\text { N-(2-Bromocyclopent-2-enyl)-N-(2-nitrophenyl) } \\
\text { methanesulfonamide }\end{array}$ & $\mathrm{C}_{12} \mathrm{H}_{13} \mathrm{BrN}_{2} \mathrm{O}_{4} \mathrm{~S}$ & 360 & 1.38 \\
\hline 6. & 11.57 & 1-Propylthio-3,3,3-trifluoropropyl acetate & $\mathrm{C}_{8} \mathrm{H}_{13} \mathrm{~F}_{3} \mathrm{O}_{2} \mathrm{~S}$ & 230 & 0.61 \\
\hline 7. & 13.19 & (+-)-trans-2-(2,5-Octdiynyl)-3-undecyloxirane & $\mathrm{C}_{21} \mathrm{H}_{34} \mathrm{O}$ & 302 & 2.47 \\
\hline 8. & 13.17 & n-Undecanol & $\mathrm{C}_{11} \mathrm{H}_{24} \mathrm{O}$ & 172 & 6.41 \\
\hline 9. & 14.96 & cis-1-Bromo-2,2,3-trimethylcyclopropane & $\mathrm{C}_{6} \mathrm{H}_{11} \mathrm{Br}$ & 162 & 1.40 \\
\hline 10. & 16.45 & $\begin{array}{l}\text { trans-1-(1-Chloro-1-methylethyl)-2,2,3,3,4- } \\
\text { pentamethylcyclobutane }\end{array}$ & $\mathrm{C}_{12} \mathrm{H}_{23} \mathrm{Cl}$ & 202 & 0.64 \\
\hline 11. & 17.25 & heptyl pentadecafluorooctanoate & $\mathrm{C}_{15} \mathrm{H}_{15} \mathrm{~F}_{15} \mathrm{O}_{2}$ & 512 & 1.17 \\
\hline 12. & 17.80 & n-Hexadecene & $\mathrm{C}_{16} \mathrm{H}_{32}$ & 224 & 12.08 \\
\hline 13. & 19.12 & Cis 3-Hexenyl Tiglate & $\mathrm{C}_{11} \mathrm{H}_{18} \mathrm{O}_{2}$ & 182 & 1.01 \\
\hline 14. & 19.38 & 8-Pentadecanone & $\mathrm{C}_{15} \mathrm{H}_{30} \mathrm{O}$ & 226 & 0.81 \\
\hline 15. & 22.24 & n-Octadecanol & $\mathrm{C}_{18} \mathrm{H}_{38} \mathrm{O}$ & 270 & 10.70 \\
\hline 16. & 24.07 & Docosane & $\mathrm{C}_{22} \mathrm{H}_{46}$ & 310 & 2.19 \\
\hline 17. & 25.21 & Heptanoic acid, methyl ester & $\mathrm{C}_{8} \mathrm{H}_{16} \mathrm{O}_{2}$ & 144 & 0.97 \\
\hline 18. & 26.22 & $\mathrm{n}$-Tricosane & $\mathrm{C}_{23} \mathrm{H}_{48}$ & 324 & 0.82 \\
\hline 19. & 26.68 & n-Decyl prop-2-ynoate & $\mathrm{C}_{13} \mathrm{H}_{22} \mathrm{O}_{2}$ & 210 & 9.61 \\
\hline 20. & 28.32 & 2-methyl-3-tetrahydrofuran-2'-ylpropanoic acid & $\mathrm{C}_{8} \mathrm{H}_{14} \mathrm{O}_{3}$ & 158 & 1.17 \\
\hline 21. & 28. 81 & Pentadecanal & $\mathrm{C}_{15} \mathrm{H}_{30} \mathrm{O}$ & 226 & 1.27 \\
\hline 22. & 30.28 & 1-Deutero-2-allyloctanol & $\mathrm{C}_{11} \mathrm{H}_{21} \mathrm{DO}$ & 170 & 2.95 \\
\hline 23. & 30.95 & Methyl (R)-3-Methyl-2-oxo[4,4,4-D3] butanoate & $\mathrm{C}_{6} \mathrm{H}_{7} \mathrm{D}_{3} \mathrm{O}_{3}$ & 130 & 4.91 \\
\hline 24. & 33.33 & 2-(2-Tetrafuryl) methyltetrahydropyran & $\mathrm{C}_{10} \mathrm{H}_{18} \mathrm{O}_{2}$ & 170 & 0.70 \\
\hline 25. & 35.02 & 2-Propyldecan-1-ol & $\mathrm{C}_{13} \mathrm{H}_{28} \mathrm{O}$ & 200 & 2.24 \\
\hline 26. & 36.97 & (E)-3-Octen-2,5-dione & $\mathrm{C}_{8} \mathrm{H}_{12} \mathrm{O}_{2}$ & 140 & 0.63 \\
\hline 27. & 38.97 & Citronellyl isobutyrate & $\mathrm{C}_{14} \mathrm{H}_{26} \mathrm{O}_{2}$ & 226 & 0.76 \\
\hline 28. & 41.54 & Di(1-adamantyl) acetic acid & $\mathrm{C}_{22} \mathrm{H}_{32} \mathrm{O}_{2}$ & 328 & 4.03 \\
\hline 29. & 43.65 & Diethyl [2-(t-butyl)-4-oxopentyl]phosphonate & $\mathrm{C}_{13} \mathrm{H}_{27} \mathrm{O}_{4} \mathrm{P}$ & 278 & 0.91 \\
\hline 30. & 44.15 & Methyl ethyl 2,2,4-trichlorotridecanoate & $\mathrm{C}_{16} \mathrm{H}_{27} \mathrm{C}_{13} \mathrm{O}_{4}$ & 388 & 2.34 \\
\hline
\end{tabular}

The presences of 30 compounds belong to the various groups like alcohol, alkane, esters, aldehyde, amide, acids and ketone. Higher value of alkane (n-tricosane and n-docosane) and alcohol groups (n-octanol, ndodecanol) were common in the present study. Some of the identified major components were n-Propanol $(19.12 \%), \quad n$-Hexadecene $\quad(12.08 \%), \quad n$-Octadecanol $(10.70 \%)$, n-Decyl prop-2-ynoate $(9.61 \%)$, n-Undecanol $(6.41 \%)$ and minor compounds like Pentadecanal $(1.27 \%)$, Docosane (2.19\%), 4-methyl-4-nitro-5oxoheptanal $(0.86 \%)$, n-Tricosane $(0.82 \%)$. The highest peak area percentage of $19.12 \%$ was obtained by 1 Propanol (RT=3.04 min.) and lowest peak area percentage of $2.34 \%$ was obtained by 1-Propylthio3,3,3-trifluoropropyl acetate ( $\mathrm{RT}=11.57 \mathrm{~min}$.).

Among the identified phytochemicals, n-Propanol, nUndecanol and n-Octadecanol is an alcohol group noted for its potent chemo preservative and anti-tumor agent [20], deodorant in cosmetic products [21], antifungal activity reported by Ramage et al. [22] The compound alkane (n-Hexadecene and Docosane) has been suggested to function as anti-microbial activity. Heptanoic acid, methyl ester and Citronellyl isobutyrate is an ester group, which is widely used as a flavoring agent and is known to possess insect repellent and anti-microbial properties. [23] The compounds citronellyl isobutyrate were reported by earlier worker. [15] Further in the present study, Aldehydes (4-methyl4-nitro-5-oxoheptanal, pentadecanal) were known to possess powerful anti-microbial activity and 8-
Pentadecanone, a ketone has compound has activity against acne treatment. [24] Thus GC-MS analysis is the first step towards understanding the nature of active principles in this medicinal plant. However, isolation of individual phytochemical constituents may proceed to find a novel drug.

Plant and plant products are being used as a source of medicine since long back. Plants are endowed with diverse range of secondary metabolites whose roles within plants are elusive. Taking into consideration the medicinal importance of Elaeocarpus serratus, the ethanolic seed extract were analysed for the first time using GC-MS. The presence of various bioactive compounds justifies the use of this plant for various ailments by traditional practitioners. From the present study, it was concluded that the plant E. serratus are highly valuable in medicinal usage for the treatment of various human ailments along with the chemical constituents present in it. The compounds needs further research on toxicological aspects to develop a safe drug.

\section{ACKNOWLEDGEMENT}

Thanks to the South India Textile Research Association (SITRA), Coimbatore, Tamil Nadu, India for GC-MS analysis.

\section{REFERENCES}

1. Muthulakshmi A, Mohan VR. GC-MS analysis of bioactive components of Feronia elephantum correa (Rutaceae). App. Pharmac. Sci. 2012; 2: 69-74. 
2. Bobbarala V, Bramhachari PV, Ravichand J, Reddy YHK, Kotresha D, Chaitanya KV. Evaluation of hydroxyl radical scavenging activity and HPTLC fingerprint profiling of Aegle marmelois (L.) Correa extracts. J Pharm Res. 2011; 4(1): 252255 .

3. Sharma P, Kaushik S, Jain A, Sikarwar SM. Preliminary phytochemical screening and HPTLC fingerprinting of Nicotiana tabacum leaf .J Pharm Res. 2010; 3(5): 1144-1145.

4. Ncube NS, Afolayan AJ, Okoh AI, Assessment techniques of antimicrobial properties of natural compounds of plant origin: Current methods and future trends. African J Biotechnol. 2008; 7: 1797-1806.

5. Lal C, Verma LR. Use of certain bio-products for insect-pest control. Indian Journal of Traditional Knowledge. 2006; 5(1): 79- 82 .

6. Bhuyan P, Khan ML, Tripathi RS. Regeneration status and population structure of Rudraksh (Elaeocarpus ganitrus Roxb.) in relation to cultural disturbances in tropical wet evergreen forest of Arunachal Pradesh. Current Science. 2002; 83 (11): 1391-1394.

7. Singh RK, Acharya SB, Bhattacharya SK. Pharmacological activity of Elaeocarpus sphaericus. Phytother. Res. 2000; 14: 3639.

8. Pullaiah T. Encyclopedia of world medicinal plants Volume2, Regency Publication, New Delhi, 2006, p. 852-853.

9. Geetha DH, Jayashree I, Rajeswari M. In vitro anti-arthritic activity of Elaeocarpus serratus Linn. (Elaeocarpaceae). International Journal of Pharmaceutical Sciences and Research. 2015; 6(6): 2649-2651.

10. Geetha DH, Jayashree I, Rajeswari M. In vivo anti-arthritic activity of ethanolic extracts of Elaeocarpus serratus L. International Journal of Pharmaceutical Sciences Review and Research. 2018; 48(2): 92-97.

11. Jayashree I, Geetha DH, Rajeswari M. Evaluation of antimicrobial potential of Elaeocarpus serratus L. Int J Pharm Sci Res. 2014; 5(8): 3467-3472.

12. Jayashree I, Geetha DH, Rajeswari M. In vitro anti-microbial activity of Elaeocarpus tuberculatus Roxb. International Journal of Pharmaceutical Sciences Review and Research. 2018; 49(1): 50-54.
13. Geetha DH, Jayashree I, Rajeswari M. Evaluation of in vitro anti-diabetic activity of Elaeocarpus serratus Fruit. International Journal of Pharmaceutical and Phytopharmacological Research. 2015; 5(2):1-4.

14. Geetha DH, Jayashree I, Rajeswari M. Anti-diabetic activity of ethanolic extract of Elaeocarpus serratus L. in streptozotocin-induced diabetic rats. International Journal of Pharmaceutical Sciences and Drug Research. 2016; 8(1): 01-06.

15. Geetha DH, Rajeswari M, Jayashree I. Chemical profiling of Elaeocarpus serratus L. by GC-MS. Asian Pac J Trop Biomed. 2013; 3(12): 985-987.

16. Geetha DH, Jayashree I, Rajeswari M. GC-MS analysis of ethanolic extract of Elaeocarpus serratus L. European Journal of Pharmaceutical and Medical Research. 2015; 2(2): 296-302.

17. Mukherjee PK. Quality Control of Herbal Drugs. An approach to evaluation of botanicals. Edition 1st published by Business Horizons, New Delhi, 2002, p. 390-403.

18. Mc Lafferly FW. Registry of mass spectral data, ed.5, Wiley New York. 1989.

19. Stein SE. National Institute of Standards and Technology (NIST) Mass Spectral Database and Software, Version 3.02, USA. 1990.

20. Joo JH, Jetten AM. Molecular mechanisms involved in farnesol-induced apoptosis. Cancer Lett. 2009; 287(2):123-135.

21. Kromidas L, Perrier E, Flanagan J, Rivero R, Bonnet I. Release of antimicrobial actives from microcapsules by the action of axillary bacteria. Int J Cosmet Sci. 2006; 28(2):103-108.

22. Ramage G, Saville SP, Wickes BL, López-Ribot JL. Inhibition of Candida albicans biofilm formation by farnesol, a quorumsensing molecule. Applied and environmental microbiology. 2002 Nov 1;68(11):5459-63.

23. Schmidt E, Jirovetz L, Buchbauer G, Denkova Z, Stoyanova A, Murgov I, Geissler M. Antimicrobial testings and Gas Chromatographic Analyses of Aroma Chemicals. J. Essent Oil-Bearing Plants. 2005; 8(1): 99-106.

24. Muthuchelian K, Raja Rajeswari N, RamaLakshmi S. GC-MS analysis of bioactive components from the ethanolic leaf extract of Canthium dicoccum (Gaertn.) Teijsm \& Binn. J. Chem. Pharm. Res. 2011; 3(3): 792-798.

HOW TO CITE THIS ARTICLE: Geetha DH, Jayashree I, Rajeswari M. GC-MS Analysis of Bioactive Compounds of Ethanolic Seed Extract of Elaeocarpus serratus. Int. J. Pharm. Sci. Drug Res. 2019; 11(1): 31-34. DOI: 10.25004/IJPSDR.2019.110105 